\title{
Law and Legal Theory
}

Edited by

Thom Brooks

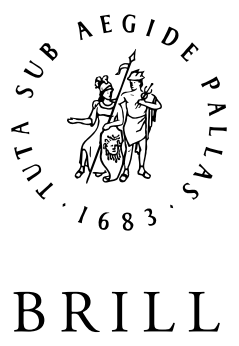

LEIDEN $\cdot$ BOSTON

2014

(C) 2014 Koninklijke Brill NV ISBN 9789004247741 


\section{CONTENTS}

Introduction

. .1

Thom Brooks

PART ONE

\section{LAW AND DEMOCRACY}

1. Review Article: Democracy, Law and Authority.

Samantha Besson

2. Rorty, the First Amendment and Antirealism: Is Reliance upon Truth Viewpoint-Based Speech Regulation?

Brian E. Butler

3. Is There a Right to Polygamy? Marriage, Equality and Subsidizing Families in Liberal Public Justification 43

Andrew F. March

PART TWO

LEGAL NORMS

4. The Ideality of Law

Sean Coyle

5. Review Article: Legal Theory, Law, and Normativity. 93 Leonard Kahn

6. Review Article: Raz on the Social Dependence of Values 105 Hanoch Sheinman

PART THREE

LEGAL REASONS

7. Legal Reasons: Between Universalism and Particularism 121 María Cristina Redondo

(C) 2014 Koninklijke Brill NV ISBN 9789004247741 
8. Criminal Harms

Thom Brooks

9. On the Non-Instrumental Value of Basic Rights 163 Rowan Cruft

10. Group Rights and Group Agency 185 Adina Preda

PART FIVE

PUNISHMENT

11. State Denunciation of Crime

Christopher Bennett

12. Imprisonable Offenses

Richard L. Lippke

13. Punishing the Guilty, Not Punishing the Innocent Richard L. Lippke

14. 'Who's Still Standing?' A Comment on Antony Duff's

Preconditions of Criminal Liability .285 Matt Matravers

15. The Paradox of Forgiveness 299

Leo Zaibert

Bibliography

Index 


\title{
REVIEW ARTICLE: DEMOCRACY, LAW AND AUTHORITY
}

\author{
Samantha Besson
}

L.H. Meyer, S.L. Paulson and T.W. Pogge (eds.), Rights, Culture, and the Law: Themes from the Legal and Political Philosophy of Joseph Raz (Oxford: Oxford University Press, 2003), 282 pp. ISBN 0199248257 (hbk). £35.oo.

Published in the same year and in the same series as another collection of essays dedicated to Joseph Raz's writings on moral philosophy, ${ }^{1}$ Rights, Culture, and the Law brings together original essays on some of the main issues of his legal and political philosophy. The book comprises thirteen chapters and a final chapter in which Raz comments on and replies to the foregoing essays. The chapters are divided in two parts: one entitled 'Issues in Jurisprudence and Legal Philosophy' with six essays addressing issues as varied as the nature of law, practical reason, authority and gaps in the law; and the other part 'Perspectives on Liberal Society', which gathers seven essays on themes such as equality, incommensurability, group rights and multiculturalism.

The essay format together with the uneven quality of the essays make it difficult for the reviewer to do justice to the rich range of issues addressed. As a choice has to be made, I shall concentrate on a single essay, Jeremy Waldron's 'Authority for Officials' (pp. 45-69) and on Raz's reply (pp. 259-64). Such a focus is justified by virtue of the fact that this chapter pertains to legal authority, and thus to one of Raz's seminal contributions to legal philosophy, and throws light on a growing challenge for Raz's service conception of authority. This challenge is that of democracy and, more generally, of accommodating the importance of law-making procedures and their publicity for legal legitimacy. ${ }^{2}$ In conditions of

1 R.J. Wallace, P. Pettit, S. Scheffler and M. Smith (eds.), Reason and Value: Themes from the Moral Philosophy of Joseph Raz (Oxford: Oxford University Press, 2003).

2 See, e.g., J. Waldron, Law and Disagreement (Oxford: Oxford University Press, 1999); S. Hershowitz, 'Legitimacy, Democracy and Razian Authority', Legal Theory 9 (2003), pp. 201-20; S. Besson, The Morality of Conflict. A Study of Reasonable Disagreement in the Law (Oxford: Hart Publishing, forthcoming [2005]). This resurgence of interest for democratic authority is also due to Waldron's and others' different attempts over the last ten years to promote a coordination-based conception of law, which culminates in the essay presently reviewed. See, e.g., J. Waldron, 'Special Ties and Natural Duties', Philosophy and Public Affairs 22 (1993), pp. 3-30; J. Waldron, 'Lex Satis Justa', Notre Dame Law Review 75 (2000), pp. 1829-58. See also before him, J. Finnis, Natural Law and Natural Rights 
reasonable disagreement about matters of common concern, it is in the publicity and the procedural nature of our legal settlements that much of the justification of law's authority lies. ${ }^{3}$ In fact, the particular importance of Waldron's essay in the collection is attested by the length of Raz's response, his acknowledgement of the 'illuminating' (p. 261) nature of Waldron's remarks, and his concession of an additional 'condition for the legitimacy of an authority' following his acknowledgement of the force of 'one of Waldron's criticisms' (p. 264). The present review is therefore situated halfway between a critical study of Waldron's essay in Rights, Culture, and the Law and an overview of the current debate over the accommodation of democratic law-making procedures in Raz's account of legal authority.

\section{Waldron's Argument}

'In philosophical discussions of authority', says Waldron, 'we usually have in mind a confrontation between an official and a subject' (p. 45). His argument is that there are other questions of authority to consider and in particular authority as between officials or institutions. In short, this implies taking a broader look at what is at stake in the relationship between a citizen and an official. As Waldron acknowledges, indeed,

...it is usually not possible to understand the relation between one official or institution and another without understanding the relation between officialdom in general and those over whom officialdom ultimately rules (ordinary citizens). The relations come in one package. (p. 45)

Waldron's argument is inspired by the 'principle of institutional settlement' (PIS) as expounded by the Legal Process scholars of the 1950s. According to this principle, 'decisions which are the duly arrived at result

(Oxford: Clarendon, 1980); J. Finnis, "The Authority of Law in the Predicament of Contemporary Social Theory', Journal of Law, Ethics and Public Policy 1 (1984), pp. 115-37; J. Finnis, 'Law as Coordination', Ratio Juris 2 (1989), pp. 97-103, as well as G. Postema, 'Coordination and Convention at the Foundations of Law', Journal of Legal Studies 11 (1982), pp. 165-203; G. Postema, 'Law's Autonomy and Public Practical Reason', in R. George (ed.), The Autonomy of Law (Oxford: Clarendon, 1996), p. 79.

3 Public authority and the authority of democratic law are too important a dimension of daily law-making to be analysed as a special case of political and legal authority in general. Of course, this does not necessarily imply that Razian authority should be able to account for political and legal authority without further conditions (p. 263). These are restrictive conditions, however, whereas, as we will see, some instances of public authority cannot even be captured as cases of general practical authority in the Razian account as it is. 
of duly established procedures ought to be accepted as binding upon the whole society unless and until they are duly changed. ${ }^{4}$ The principle applies to citizens as much as to institutions and officials. With respect to the latter, 'the principle characteristically commands respect for a given settlement from other bodies whose function it might also be, in certain circumstances, to arrive at binding settlements' (p. 47). Waldron argues by reference to Raz that 'a theory of authority is not just a list of the conditions under which an authority claim is justified: it must also illuminate the justificandum' (p. 49). Thus, for PIS to be deemed the basis of a theory of authority, 'a duly arrived at settlement should be respected only if the following condition is justified: "Human interdependence generates questions of common concern which have to be settled, one way or another"' (p. 49). Something is a question of common concern, says Waldron, 'if it is better for a single answer to be accepted among [the parties] than for each person to deal with the question on his own, as best he can, as far as it affects or interests him, acting unilaterally on the basis of his own answer' (p. 49). To summarize,

.... a duly arrived at settlement $X$ should be respected by the members of the group $G$, only if the following condition is satisfied: $X$ is chosen from a set of answers to a question arising in $G$ such that, for each item in that set of answers, it would be better that that answer be adopted by all the individuals in $\mathrm{G}$ than that each individual in $\mathrm{G}$ select and act unilaterally on his own answer to the question. (p. 5o)

This is not a sufficient explanation of institutional settlement. As Waldron argues, 'we still need to analyse "duly arrived at"' (p. 50). Duly established settlements are settlements reached according to publicly recognized procedures. What is needed is for the salience of one of the options at stake to be revealed, that is: 'for one of the options to be marked for all the members to see as the one for everyone to follow' (p. 53). This applies to pure coordination problems as much as to partial conflict coordination problems, that is to say, cases where there are several ways of disposing of a question of common concern but where, respectively, some involve options among which everyone is indifferent, while others may involve options over which people disagree (pp. 50-52). It also applies, however, to cases where there is only one option and everyone converges on it, as we need to know that this question of common concern has been answered

${ }^{4}$ H.M. Hart and A.M. Sacks, in W.N. Eskridge and P.P. Frickey (eds.), The Legal Process: Basic Problems in the Making and Application of Law (Westbury, NY: Foundation Press, 1994), p. 4. 
officially and that it is now time for this option to be enforced (p. 51). Publicly established settlements like law provide new reasons for us to act upon; the law is such that it can provide signals of salience of the appropriate kind. We share an attitude towards it and a practice 'of looking to it for solutions to problems of this sort, being alert to its dispositions, communicating this alertness to others, and refraining from doing anything to diminish the confidence that others may have in the appropriateness of regarding the outputs of this procedure as salient' (p. 54). Waldron unpacks four elements of the respect one owes to such a publicly established settlement as law:

First, one must acknowledge that what is at stake is a question of common concern; second, one must recognize the presence of established arrangements for producing answers to such questions; third, one must ascertain whether such arrangements have actually produced a decision that answers the question; and, fourth, if they have, one must play one's part in the social processes that are necessary to sustain and implement such decision as settlement. (p. 56)

This model of the authority of publicly established settlement applies equally to citizens and officials (p. 69). The novelty in Waldron's argument lies, of course, in inter-official and inter-institutional authority. As Waldron argues, like a citizen, 'by holding out for his own, and by choosing unilaterally to run the risk of society's failing to settle on and implement a common answer to the question, [the official] is making light of efforts that have been made already to solve these problems' (p. 57). But this is even more serious on the part of an official, 'when ordinary citizens must take their cues from the behaviour of officials as to when a settlement has been duly enacted'; 'it is important', indeed, 'that these cues be available and reliable so that citizens know when it is appropriate for them to defer to a decision' (p. 57). After all, as Waldron argues, the officials' relationships among themselves are about their relationships to citizens as a whole and their authority over them (p. 67). Thus, it is only if they do not disrupt that relationship that they can have legitimate authority over citizens, and this can only be the case if they coordinate over what citizens should coordinate over (pp. 67-69). Waldron concludes therefore that

[o]nce an official directive has been issued that holds a fair chance of securing coordination among the citizens, other officials ought to be prepared to swallow hard and refrain from issuing contrary directives, even when they are convinced that it would be better for the citizens to coordinate on their directive rather than on the basis of the one that has already been issued. (p.69) 
The remainder of Waldron's essay assesses whether this account of public authority can be accommodated 'within the four walls' of Raz's conception of authority which he deems as 'the richest and most fertile account we have' (p. 69). His argument is that it can be, provided the latter is revised to accommodate the public dimension of law's authority (pp. 59-66). In this review, I would like to separate two lines of argument in Waldron's complex essay: first, the connexion between officials' authority over citizens and authority among officials and, second, the compatibility between Raz's account of authority, on the one hand, and the legitimacy of democratic law or its procedural legitimacy, on the other. It is important to keep both arguments apart, since the latter applies to both authority for citizens and authority for officials and may therefore apply independently however successful the former may be.

\section{From Authority for Citizens to Coherence for Officials}

According to Waldron, authority for officials not only mirrors authority for citizens, but is a direct consequence of it within the package of relations between these different actors. It is important, however, to distinguish more clearly between the nature of the authority for citizens and that for officials and institutions.

Waldron is right to argue that inter-official relationships are about their relationships to citizens and their authority over them (p. 67). Accordingly, they give rise to second-order obligations related to the main relationship between citizens and officials and their in-built first-order obligations. Where Waldron gets it wrong, however, is when he argues that this kind of respect or deference among officials is rightly called authority (pp. 55-59). It is the outcome or the reflexion of officials' authority over citizens, but it is not authority per se. True, one may refer to authority on the part of officials when they are regarded as citizens, but when they are wearing their additional officials' cap, it is another principle of public morality which applies to them. This principle is coherence, ${ }^{5}$ i.e. consistency in principle.

Coherence requires that officials 'speak with just one voice', to borrow Dworkin's expression. ${ }^{6}$ What it implies is that, in conditions of reasonable disagreement where people are to coordinate over conceptions of justice, officials should try to express a unified conception of justice such that it

\footnotetext{
5 See Besson, The Morality of Conflict for a detailed argument for legal coherence.

6 See R. Dworkin, Law's Empire (London: Fontana, 1986), p. 165. See also Waldron, Law and Disagreement.
} 
can apply to a single person. Authority over citizens implies the possibility of 'authorship' on the part of citizens and this calls for coherence in the authority's directives. It is central to the law's task of guiding intelligent human action that it enable rational self-directing agents to achieve a degree of coherence, on the one hand, by relating present official directives among themselves and, on the other, by anchoring present official decisions in past decisions of officials. ${ }^{7}$ It is only when the law is coherent and applies as a system that it is able to provide the unique coordinating guidance that it is expected to give. ${ }^{8}$

The advantage of this account of inter-official and inter-institutional coherence over authority lies in the gap it preserves between principled consistency and absolute conformity. Coherence accommodates other potentially conflicting principles of deference that flow from those institutions' respective de facto constitutions, i.e. what they are in fact (p. 262). For instance, inter-institutional authority of the kind proposed by Waldron would require the legislature to defer absolutely to a prior judicial decision over which people coordinate, although this is not what the legislature's constitution requires in terms of authority. Coherence with that decision, by contrast, would ensure the consistency necessary for the coordination of citizens' actions, independently of what institutional constitutions require. Besides, either way, coherence respects the benefits of checks and balances and of inter-institutional cooperation in conditions of reasonable disagreement. ${ }^{9}$ Finally, coherence enables officials to respect and accommodate each other's diverse viewpoints and to strike principled compromises among them, instead of deferring absolutely to some of them. ${ }^{10}$

\section{Razian Authority and Democratic Legitimacy}

Even if one reduces its scope to the relationship between citizens and officials, Waldron's argument about the limits of Razian authority does not

7 G. Postema, 'Law's Melody: Time and the Normativity of Law', Associations 7.1 (2003), pp. 227-39 (234-36).

8 See p. 57: 'To assure himself that his compliance with any number of these directives is not in vain, a citizen $\mathrm{C}_{1}$ must assume that officialdom is operating coherently as a system, so that (for example) $\mathrm{C}_{1}$ is not responding to Supreme Court directives on affirmative action while his fellow citizens $\mathrm{C}_{2}, \mathrm{C}_{3}$ etc. are responding to contrary legislative directives.'

9 See Besson, The Morality of Conflict.

10 See S. Besson, 'Four Arguments Against Compromising Justice Internally', Oxford Journal of Legal Studies 23.2 (2003), pp. 211-41. 
lose any of its bite. In drawing on this argument and Raz's reply and taking them further, I will sketch a revised account of Raz's conception of authority that can accommodate the public and collective dimensions of legal authority. There are three theses that need to be satisfied before a public authority can be regarded as a justified authority in Raz's account: the preemption thesis, the dependence thesis and the normal justification thesis. Note that although I am assuming for reasons of space that Waldron's coordination-based argument for public authority is correct, the following reasoning can be understood independently of the validity of coordination-based arguments. ${ }^{11}$ Democracy, and collective law-making procedures, more generally raise difficulties for Raz's account of authority that pertain to their public and collective character. ${ }^{12}$

\subsection{The Pre-Emption Thesis}

According to this first thesis, the subjects of an authority can benefit from its directives 'only if they can establish their existence and content in ways which do not depend on raising the very same issues which the authority is there to settle. ${ }^{13}$ It is only so that these directives can make a practical difference to the deliberations of those to which they apply. According to Raz,

[t] he fact that an authority requires performance of an action is a reason for its performance which is not to be added to all other relevant reasons when assessing what to do, but should exclude and take the place of some of them. ${ }^{14}$

This condition is respected in Waldron's account of public authority, since the point of the legal settlement of a disagreement is precisely a matter of setting aside the substantive reasoning that brought us to this problem in the first place. ${ }^{15}$ Legal coordination, and settlements more generally, are only possible if the parties can identify the salient option without having to engage in the reasoning that was necessary to get to that decision and, most importantly, without having to disagree again on what it should be.

11 Raz argues that coordination is not law's only function and understands coordination in the impoverished sense given by Lewis and others of coordination of interests, rather than of common concerns (p. 259). See Besson, The Morality of Conflict, for a critique and an account of the nature of coordination-based obligations to obey the law.

12 See, e.g., Hershowitz, 'Legitimacy, Democracy and Razian Authority'.

13 J. Raz, Ethics in the Public Domain (Oxford: Oxford University Press, 1995), p. 203.

14 J. Raz, The Morality of Freedom (Oxford: Clarendon, 1986), p. 46.

15 See p. 6o. See also Finnis, 'Law as Coordination', p. $101 \mathrm{ff}$. 
The only departure from the pre-emption thesis, however, lies in the identification of a public authority. According to Waldron, this identification should result from the awareness of the existence of a question of common concern that needs coordination (pp. 6o-61) or a legal settlement, first, and from the awareness of others' participation in a coordinative or legal effort (pp. 49, 59), second. If one follows the pre-emption thesis very strictly, however, the law must, in order to be authoritative, precisely preempt the subject's own reasoning in determining when we are actually facing disagreement and a coordination problem and when we need authority. ${ }^{16}$ This implies that there is a way of identifying the law's authority without having to engage in the sort of activity that was necessary to produce it and therefore without figuring that we are actually facing a coordination problem.

This discrepancy need not worry us too much, however, and Waldron gives up somewhat too quickly on Razian authority. Even in Raz's account, true respect for and acceptance of a decision as being authoritative, by contrast to mere submission to it (pp. 6o-61), cannot arise without first observing that the question is a question of common concern that needs a legal settlement and that there is a legal scheme at work. It is often wrongly assumed that to abide by an exclusionary reason for action implies that one ought not to think about other reasons. All an exclusionary reason does is pre-empt people from acting for an excluded reason and not from thinking about it or concurrent reasons. ${ }^{17}$ One needs to be able to identify an authority and determine whether it has the abilities it claims to be a legitimate authority in certain matters and classes of cases, before the authority can apply and pre-emption can take place.

One may refer to this additional condition to the pre-emption thesis as the knowability of authority. ${ }^{18}$ In fact, Raz concedes this point in his reply to Waldron and contends that

16 See J. Raz (ed.), 'Introduction', in Authority (Oxford: Blackwell, 199o), p. 10; Raz, The Morality of Freedom, pp. 203, 209.

17 See J. Raz, Practical Reason and Norms, 2nd edn (Oxford: Oxford University Press, 1999), p. 184.

18 This process of identification of an authority is clearly evaluative. One may therefore question its compatibility with Raz's practical difference thesis, but more particularly with the sources thesis. True, there remains a gap between identifying an authority in a general class of cases and determining the merits of each of its decisions. Besides, Raz might want to reduce the scope of the practical difference and sources theses to cases of de facto legal and political authority, for the recognition of which the three theses including the preemption thesis and its knowability addendum need not be given. It is not entirely clear, however, how this last move might be of interest to any account of authority whose ultimate claim is bound to be legitimacy. 
[i]t seems plausible to add a condition for the legitimacy of an authority. Something like a requirement that people over whom it has authority should have reason to find out, and should be able to find out whether it has such authority (at a cost not disproportionate to the benefit in tracking the reason its supposed authority can bring). Perhaps it should also be a condition of the authoritative standing of any directive that those subject to it have reason to find out whether it exists and can find out its content. (p. 264)

\subsection{The Dependence Thesis}

What the dependence thesis implies is that there can be no separate set of reasons for authorities to use that would not in principle be appropriate for the subjects of the authorities to use (p. 62). According to Raz, 'all authoritative directives should be based on reasons which already independently apply to the subjects of the directives and are relevant to their action in the circumstances covered by the directives. ${ }^{19}$ In a disagreement, the problem arises from the fact that very different sets of reasons dictate the different participants' conflicting opinions about what should be done. By the time they decide to settle their disagreement, therefore, the set of reasons underlying the salient directives cannot correspond to all the potential reasons underlying each of the individual opinions (p. 61). Besides, the presence or possibility of an authority changes the nature of the choices participants face, thus making it difficult to associate the authoritative set of reasons with each and all of the choices possible, apart from the existence and actions of the authority (p. 62). For instance, the emergence of a coordination problem and the possibility of coordination give rise to reasons to coordinate which people might not have had before. According to Waldron, therefore, Raz's model is appropriate only in cases where a person's choice on the merits roughly identifies with the choice on the merits as options for the entire population, that is to say, in cases where there is no disagreement and hence no need for coordination (p. 62).

Interestingly, Raz concedes this in his reply. His recent re-interpretation of the thesis states that it does not require that the reasons for action authorities provide correspond perfectly to existing individual reasons for action. Arguing the contrary would imply that the existence of a public authority could not enable us to achieve desirable goals which would be unachievable without it. All the dependence thesis requires therefore is that we have the abstract reasons which the public authority gives us new

19 Raz, Ethics in the Public Domain, p. 47. 
opportunities to pursue, even though we did not have the opportunity to do so on our own (p. 26o). Thus, the dependence relationship can be indirect and fit cases where disagreement and the presence of an authority change the nature of the choices people face.

\subsection{The Normal Justification Thesis}

According to the normal justification thesis, we must be able to comply better with our own reasons by abiding by authoritative decisions than on our own, whether or not we believe we do. The normal justification thesis is not based on a subjective assessment of what is in our reasons' best interest, but on an objective truth. According to Raz,

...the normal and primary way to establish that a person should be acknowledged to have authority over another person involves showing that the alleged subject is likely better to comply with reasons which apply to him (other than the alleged authoritative directives) if he accepts the directives of the alleged authority as authoritatively binding and tries to follow them rather than if he tries to follow the reasons which apply to him directly. ${ }^{20}$

Like the other two, this third thesis is in need of thorough revision, if it is to accommodate the reality of democratic law-making in conditions of reasonable disagreement, and, more particularly, the law's public and collective dimension.

\subsection{A First Challenge: The Need for Public Identification}

As Waldron argues, what the normal justification thesis fails to capture from the start is an important dimension of legal and political authority: its public and shared dimension (p. 65). Before an official or an institution can be an authority in an individual case, it ought to be publicly known as such and its procedures be supported by a shared practice of recognition. Only this way can it then be deemed to provide the salient decisions necessary for coordination to take place and hence be able to make a practical difference at the individual level. As Waldron argues,

...it may be quite inappropriate for me to regard A as a public authority unless I am sure that many others do in fact so regard it (or are prepared to do so if they see that enough others are prepared to do so if... etc.). (p. 66)

As we saw earlier, Raz concedes this point in his reply to Waldron by adding a condition to the normal justification thesis: the knowability of

20 Raz, The Morality of Freedom, p. 198; Raz, Ethics in the Public Domain, p. 53. 
authority (p. 264). This concession implies that, for a public authority to be justified objectively in an individual case, people must be able to find out and decide whether it has the public qualities required to have authority over all of them collectively and not only individually. This leads me to formulate a second challenge which Waldron does not articulate. ${ }^{21}$

\subsection{A Second Challenge: The Need for Collective Decision-Making}

Given the conditions of reasonable disagreement that prevail and the procedural legitimacy of most of our legal decisions, ${ }^{22}$ one needs to go even further in the proceduralization of the normal justification thesis. True, in principle, it should be possible to keep the subjective identification of public authority distinct from its objective justification. This does not take the conditions of disagreement and circumstances of politics seriously enough, however. The normal justification thesis should accommodate the fact that democratic authorities make their demands ex hypothesi on people who think they have good grounds for believing that the majority is mistaken. ${ }^{23}$ In other words, any theory that makes legitimate authority depend on the moral rightness of political outcomes is self-defeating, because it is in many cases precisely because people disagree reasonably about it, and hence about the normal justification thesis, that they need to set up and recognize an authority and engage in democratic law-making procedures.

Of course, as Raz acknowledges, part of the idea of practical authority is that, to protect our individual reasons, we might have to deviate slightly from them through accepting the indirect decisions of an authority that would thus help us comply with them better than on our own. Things differ hugely, however, depending on whether one is considering a private or a public authority. The recognition and hence the establishment of public authority, although it aims eventually at binding individuals, whether in collective or purely individual actions, cannot be about individually identifying the best practical authority, by contrast to the recognition of private authority on private matters; it is indeed about collectively finding the best way to coordinate diverging opinions on matters of common concern. As such, the identification and establishment of public authority necessarily restricts the possibility of respecting a substantive form of normal

${ }^{21}$ This is probably due to his subjective account of the normal justification thesis (pp. 49, 66).

22 See Waldron, Law and Disagreement, p. 96.

23 See Waldron, Law and Disagreement, p. 101. 
justification thesis at an individual level. Paradoxically, therefore, the only way we have of complying collectively with the requirements of justice, and the reasons which apply individually to us when we disagree about justice and about how best to respect it, is to abide by the imperfect outcome of a procedure, thus intentionally placing substantive demands of justice second behind our moral interest in coordination. ${ }^{24}$

From the moment we recognize the procedural and collective dimension of the normal justification thesis, there can be no return to a purely substantive and individual account. It would be absurd to emphasize, on the one hand, the dependence of the normal justification thesis on the existence and identification of a public law-making scheme as the only way of complying with the former, while requiring, on the other, that authoritative directives comply individually with reasonably contested substantive standards of justice. Of course, this does not amount to eliminating all objectively substantive elements from the normal justification thesis. As Scott Hershowitz argues, this would make it an empty shell. ${ }^{25}$ It should, on the contrary, be conceived as a hybrid of both the procedural and substantive dimensions. In short, this revised account of the normal justification thesis should attribute authority to the outcome of a lawmaking procedure, in which we are intentionally taking part, provided this law-making scheme itself, as opposed to its outcome, is fair in each individual case. ${ }^{26}$ The law-making procedure's fairness should be assessed by reference to certain minimal objective moral standards, such as the protection of basic procedural equality in a democracy. ${ }^{27}$

24 Of course, coordination implies better compliance with one's individual reasons to coordinate, but these are not the main individual moral reasons at stake in the context of the normal justification thesis. There is indeed a difference between reasons to have an authority and reasons this authority provides us with. This confusion might explain why Waldron does not see fit to go further than the first challenge, although the normal justification thesis, as Raz understands it, is not compatible with his account of natural duties to coordinate in Waldron, 'Special Ties'.

${ }^{25}$ Hershowitz, 'Legitimacy, Democracy and Razian Authority', pp. 219-20: 'So conceived, the normal justification thesis would accommodate all theories of legitimacy that turned out to be true; hence it ceases to be a competitor with other candidate theories of legitimacy.'

${ }^{26}$ In this sense, I think that Hershowitz, 'Legitimacy, Democracy and Razian Authority', p. 220, misses the argument by blaming procedural re-interpretations of the normal justification thesis for diluting the distinction between making better decisions about the matter the directive regards and making better decisions about such questions more generally. See Besson, The Morality of Conflict.

27 See Besson, The Morality of Conflict, on this minimal substantive legitimacy of the procedural legitimacy of democratic law. See also Hershowitz, 'Legitimacy, Democracy and Razian Authority', pp. 216ff. See, more generally, J. Rawls, 'Legal Obligation and the Duty of Fair Play', in S. Freeman (ed.), John Rawls: Collected Papers (Cambridge MA: Harvard University Press, 1999). 